\title{
Detection of antibody to C-carbohydrate of group A streptococci with enzyme-treated whole bacterial cells as antigen for ELISA
}

\author{
ARCHANA THAKUR and KUNTI PRAKASH \\ WHO Reference Laboratory for Streptococcal Diseases, Department of Microbiology, Lady Hardinge Medical \\ School, New Delhi 110001, India
}

\begin{abstract}
Antibody to specific cell-wall carbohydrate of group A streptococci in human sera was determined by enzyme-linked immunosorbent assay (ELISA) with enzyme-treated whole cells and purified group $\mathrm{A}$ carbohydrate (ACHO) as antigens. The optimal concentration of enzyme-treated whole bacterial cells to coat wells was $2 \times 10^{8}$ cells $/ \mathrm{ml}$ and for purified ACHO antigen the optimal concentration was $1 \mu \mathrm{g} / \mathrm{ml}$. Sera from patients with acute rheumatic fever and acute glomerulonephritis were screened for the presence of C-carbohydrate antibodies. Patients with acute post-streptococcal complications showed significantly higher titres of antibody when compared with normal healthy individuals. ELISA results were also compared with purified ACHO as an antigen; this showed a highly significant correlation $(r=0.73)$. Results showed that measurement of the antiACHO antibody by ELISA with enzyme-treated whole cells can be a useful, reliable and simple method for serological diagnosis of group $A$ infection and sequelae.
\end{abstract}

\section{Introduction}

Several investigators have detected antibodies to streptococcal antigens in sera of patients with streptococcal infection and its sequelae [1-6]. Halpern and Goldstein [7] first utilised the radioimmune precipitin technique to quantify the levels of antibody in human serum. Subsequently, Smith and Lehner [8] developed a solid-phase immunoassay with whole bacterial cells, but this was not reliable because of the instability of bacterial adsorption to solid phase. Czerkinsky et al. [9] developed a solid-phase immunoassay with a polyaldehyde derivative (Methylglyoxal) to link bacteria directly to the solid phase. A method of measuring anti-CHO antibody by ELISA has been developed recently with purified group A streptococcal carbohydrate antigen-polyL-lysine [ACHO-PLL] complex [10]. Current serological methods for the diagnosis of streptococcal infection test for antibodies to extracellular products such as streptolysin O or DNAase B.

The present study investigated the potential advantage of ELISA for routine diagnosis of infection with group A streptococci (GAS) and sequelae with whole bacterial cells as antigen, and compared it with ELISA with purified ACHO antigen.

Received 5 Jan. 1996; accepted 28 Jan. 1996.

Corresponding author: Dr A. Thakur (present address: CRC for Eye Research and Technology, University of New South Wales, Sydney, NSW 2052, Australia).

\section{Materials and methods \\ Strain and culture}

GAS strain J-17 was grown overnight at $37^{\circ} \mathrm{C}$ in ToddHewitt broth. The cells were harvested by centrifugation at $3000 \mathrm{rpm}$ for $10 \mathrm{~min}$ and washed three times with sterile saline.

\section{Preparation of enzyme-treated whole bacterial cells}

GAS strain $\mathrm{J}-17$ was suspended in saline $0.87 \%$ and heated at $60^{\circ} \mathrm{C}$ for $45 \mathrm{~min}$, washed and suspended in $50 \mathrm{mM}$ phosphate buffer (PB) at $\mathrm{pH} 7.4$. Cells were then treated according to the method of Todome et al. [11]. Suspended cells were treated with DNAase $100 \mu \mathrm{g} / \mathrm{ml}$ and trypsin $100 \mu \mathrm{g} / \mathrm{ml}$ at $37^{\circ} \mathrm{C}$ for $4 \mathrm{~h}$. Whole cells treated with trypsin were treated again with pronase E $100 \mu \mathrm{g} / \mathrm{ml}$ containing $\mathrm{NaN}_{3} \quad 0.1 \%$ at $37^{\circ} \mathrm{C}$ overnight. Enzyme-treated whole cells were washed thoroughly with $50 \mathrm{mM} \mathrm{PB}$ and suspended at a concentration of $2 \times 10^{8}$ cells $/ \mathrm{ml}$ in methylglyoxal $0.3 \%$ at $\mathrm{pH} 8.0$ by the method described by Czerkinsky et al. [9]. Treated whole cells were used as an antigen for ELISA.

\section{Extraction of $A C H O$ antigen}

The cell walls of GAS were isolated by Mickle disintegration and differential centrifugation according to the method of Salton and Horne [12]. The cell walls 
were treated with DNAase $100 \mu \mathrm{g} / \mathrm{ml}$, RNAase $100 \mu \mathrm{g} / \mathrm{ml}$ and trypsin $100 \mu \mathrm{g} / \mathrm{ml}$ at $37^{\circ} \mathrm{C}$ for $3 \mathrm{~h}$. The enzyme-treated cell walls were washed three times with $50 \mathrm{~mm}$ PB. ACHO was then extracted from cell walls by the hot formamide method of Fuller [13] and assayed for rhamnose and glucosamine content $[14,15]$.

\section{Coupling of group A carbohydrate to poly L- lysine}

Coupling of ACHO with PLL was done by the method of Gray [16]; briefly, $2 \mathrm{mg}$ of formamide-extracted ACHO was added to $1.0 \mathrm{ml}$ of $10 \mathrm{mM} \mathrm{NaOH}, \mathrm{pH} 12$, and mixed gently for $10 \mathrm{~s}$. This solution was then transferred to a tube containing cyanuric chloride $5 \mathrm{mg}$ and mixed gently; $\mathrm{pH}$ was monitored continuously. At $\mathrm{pH} 8.4$ the supernate was transferred quickly to a tube containing $0.2 \mathrm{ml}$ of PLL, taking care to avoid transfer of cyanuric chloride crystals. The final $\mathrm{pH}$ was 8.0-8.2. The ACHO-PLL conjugate was stored at $-20^{\circ} \mathrm{C}$ in small volumes until used.

\section{Antisera production}

Antiserum was raised in rabbits against whole GAS cells and purified ACHO by the method described by McCarty and Lancefield [17]. The serum antibody was determined by gel immunodiffusion.

\section{Sera}

Serum was collected from 100 clinically and serologically diagnosed patients with post-streptococcal complications. Fifty were from cases of acute rheumatic fever (RF) and 50 from those with acute glomerulonephitis. Serum from 50 normal healthy subjects with no evidence of AGN or RF served as a control group.

\section{ELISA with ACHO-PLL complex as antigen}

ELISA was done according to the method described by Gray [16] and Barrett et al. [10] with slight modifications. Purified ACHO coupled to PLL was used as an antigen to coat the wells of the microtitration plate. Antigen diluted to $1 \mu \mathrm{g} / \mathrm{ml}$ in $10 \mathrm{mM}$ PBS, $\mathrm{pH} 7.4$, was used to coat wells of an Immunol II 96-well microtitration plate. Incubation was for $1 \mathrm{~h}$ at $37^{\circ} \mathrm{C}$ followed by overnight incubation at $4^{\circ} \mathrm{C}$. Plates were washed with phosphate-buffered saline (PBS) containing $0.05 \%$ Tween-20 and $500 \mathrm{mM} \mathrm{NaCl}$ (PBST-NaCl). PLL alone was coated as a control. Plates were blocked with BSA $1 \%$ in $10 \mathrm{~mm}$ PBS and incubated for $1 \mathrm{~h}$ at $37^{\circ} \mathrm{C}$. At the end of incubation, plates were washed three times with PBST-NaCl, then standard or samples were added, incubated at $37^{\circ} \mathrm{C}$ for $1 \mathrm{~h}$ and washed as above; this was followed by application of anti-human IgG labelled to horseradish peroxidase (HRPO). Colour was produced with 2.2-azino-di-(3-ethylbenzthazolin) sulphonic acid substrate. The OD was measured at $490 \mathrm{~nm}$.

\section{ELISA with enzyme-treated whole cell antigen}

For ELISA, wells of an Immunol II 96-well microtitration plate were coated with enzyme-treated whole cells suspended at a concentration of $2 \times 10^{8}$ cells $/ \mathrm{ml}$ in methylglyoxal (Sigma) 0.3\%, pH 8.0, adjusted with sodium bicarbonate $10 \%$. Plates were incubated at $37^{\circ} \mathrm{C}$ for $3 \mathrm{~h}$, washed three times with $50 \mathrm{mM}$ PBST and blocked with BSA $1 \%$ in PBST. After incubation for $90 \mathrm{~min}$ at $37^{\circ} \mathrm{C}$, wells were washed with PBST and human serum was added to each well and incubated at $37^{\circ} \mathrm{C}$ for $90 \mathrm{~min}$. Wells were washed and HRPOlabelled anti-human IgG or biotinylated monoclonal mouse anti-human IgG1 (clone 8c/6-39), IgG2 (clone HP-14), IgG3 (clone HP-50) and IgG4 (clone HP-25) antibodies optimally diluted and added to wells, followed by incubation with HRPO-labelled Extra avidin. Plates were washed and 2.2-azino-di-(ethylbenzthazolin) sulphonic acid was added as substrate to show colour and plates were read at $490 \mathrm{~nm}$.

\section{Results}

\section{Detection of anti-ACHO antibody in rabbit serum}

Rabbit antiserum raised against whole cell vaccine, showed a line of precipitation with purified ACHO in gel immunodiffusion. A line of precipitation with purified $\mathrm{ACHO}$ was observed up to 1 in 6400 dilution, and, with group A extract, the line was up to a 1 in 12800 dilution.

\section{Detection of $A C H O$ antibody with enzyme-treated whole cells as antigen}

Microtitration plates were coated with various concentrations of trypsin-protease-treated (T-P) whole cells ranging from $2 \times 10^{5}$ to $2 \times 10^{10} \mathrm{cells} / \mathrm{ml}(100 \mu \mathrm{l} /$ well). Serum dilutions ranging from 1 in 10 to 1 in 12800 were added to each dilution of antigen. The optimal concentration of antigen was $2 \times 10^{8}$ cells $/ \mathrm{ml}$ and the serum dilution 1 in 100 (Figs. 1 and 2). Patients' and control sera were screened for ACHO antibodies. Patients' sera showed a significant difference $(p<0.01)$ compared with controls.

\section{Distribution of IgG subclasses of antibody to ACHO}

Serum diluted 1 in 50 was used to detect $\operatorname{IgG}$ subclasses of anti-ACHO antibody. The predominant subclass of antibody found against ACHO in sera of all normal and most RF and AGN sera was IgG2. Only five $(2.5 \%)$ of $50 \mathrm{AGN}$ and seven $(3.5 \%)$ of $50 \mathrm{RF}$ patients' sera showed high titres of IgG3 subclass antibody (Fig. 3). 


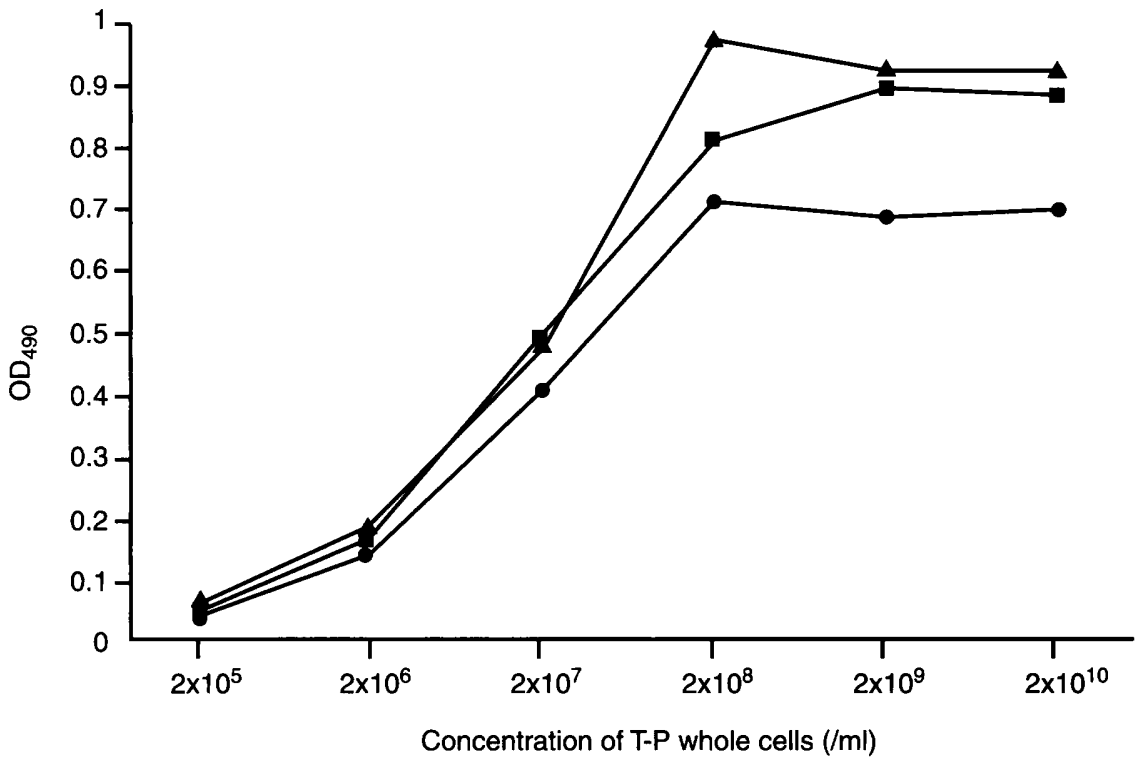

Fig. 1. Reference curve to determine optimal concentration of T-P whole cells to coat wells of ELISA plate. Serum dilutions: -,- 1 in $50 ;-\mathbf{-}, 1$ in $100 ;-0-, 1$ in 200 .

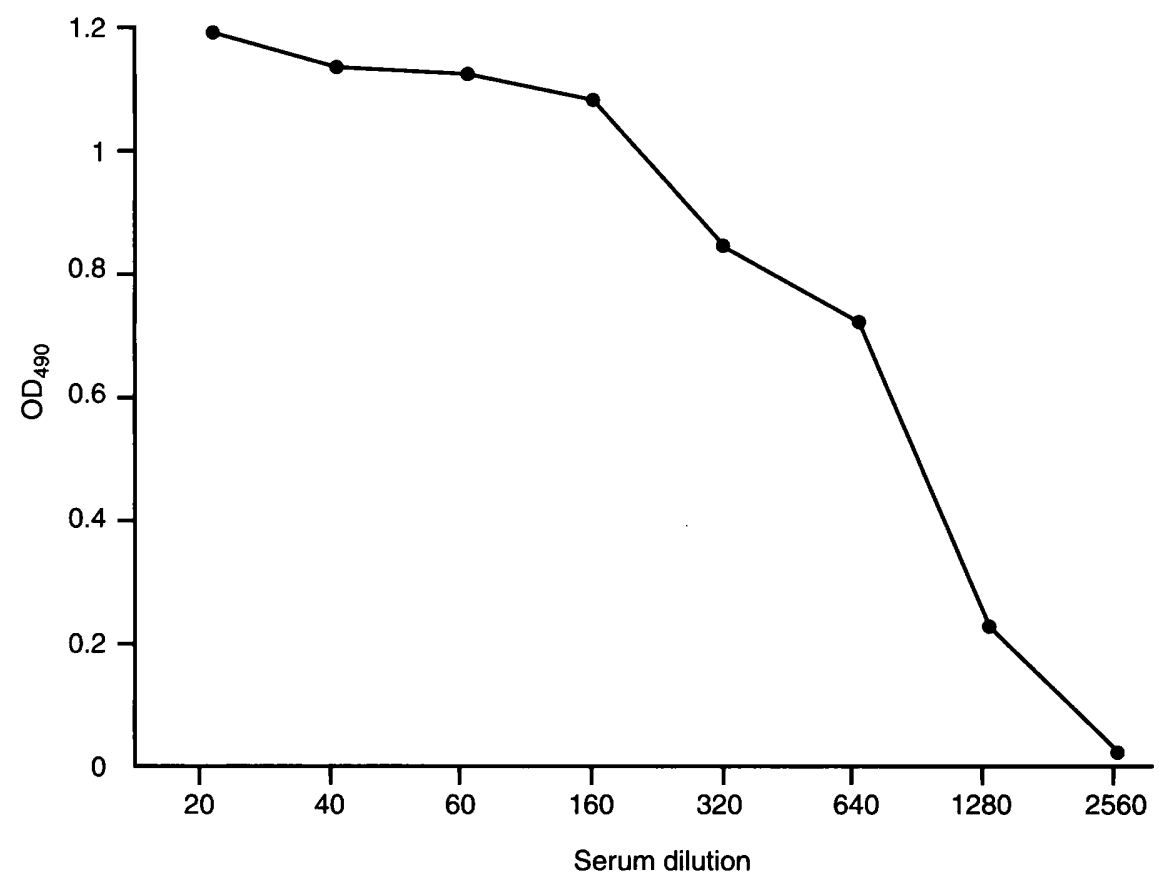

Fig. 2. Determination of optimal dilution of human serum to detect GAS anti-ACHO antibody. Wells were coated with $2 \times 10^{8}$ T-P-whole cells $/ \mathrm{ml}$.

Screening of anti-CHO antibody in human serum with ACHO-PLL complex as antigen

Antigen was diluted to $1.5,1.0,0.5,0.25$ and $0.15 \mu \mathrm{g} /$ $\mathrm{ml}$ in $10 \mathrm{mM}$ PBS, $\mathrm{pH}$ 7.4. Serum dilutions ranging from 1 in 10 to 1 in 250 were added to each dilution of antigen. The antigen diluted to $1.0 \mu \mathrm{g} / \mathrm{ml}$ showed the highest $\mathrm{OD}$ and the serum dilution showed a plateau at a 1 in 100 dilution and thereafter a decrease with further dilution (Fig. 4). These results indicate that the optimal dilution for antigen was $1.0 \mu \mathrm{g} / \mathrm{ml}$ and the serum dilution was 1 in 100; 100 sera from patients with AGN and RF and from 25 normal healthy control subjects were screened for anti-ACHO antibodies. The titres in patients' sera were significantly higher than in the control group $(p<0.01)$ (Table 1).

\section{Discussion}

Antibodies to ACHO antigen have been detected in patients with GAS infection and in those with complications such as RF and AGN. Persistence of a 


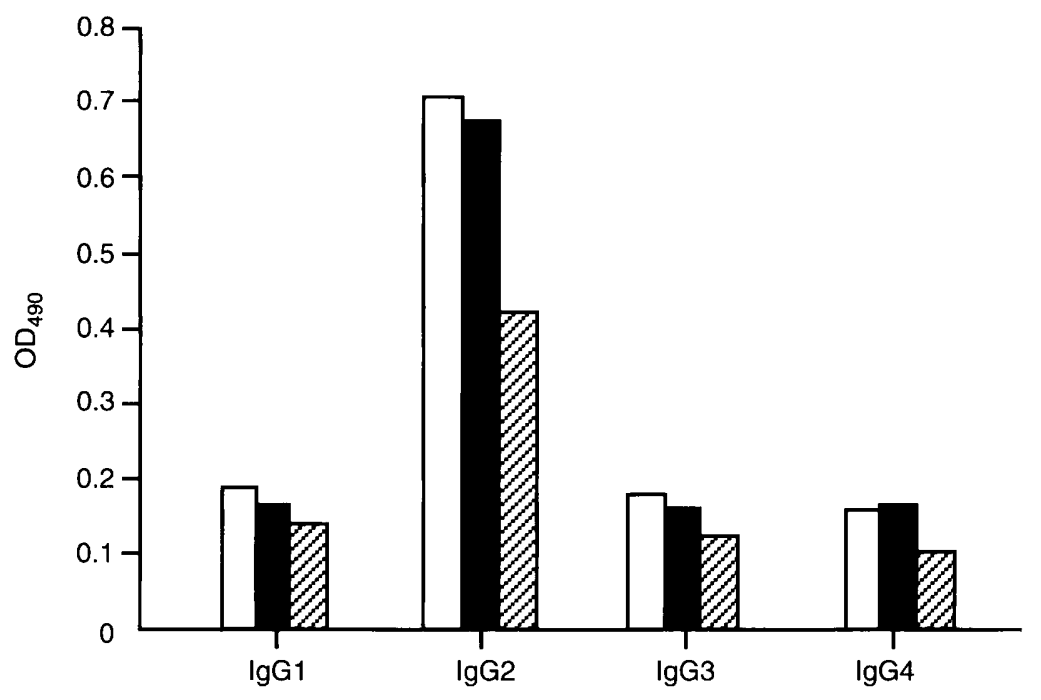

Fig. 3. Distribution of IgG subclass (IgG1, IgG2, IgG3 and IgG4) antibodies to ACHO in normal human sera ( $\mathbf{\square})$ and patients with post-streptococcal complications (AGN, $\square$; RF, ).

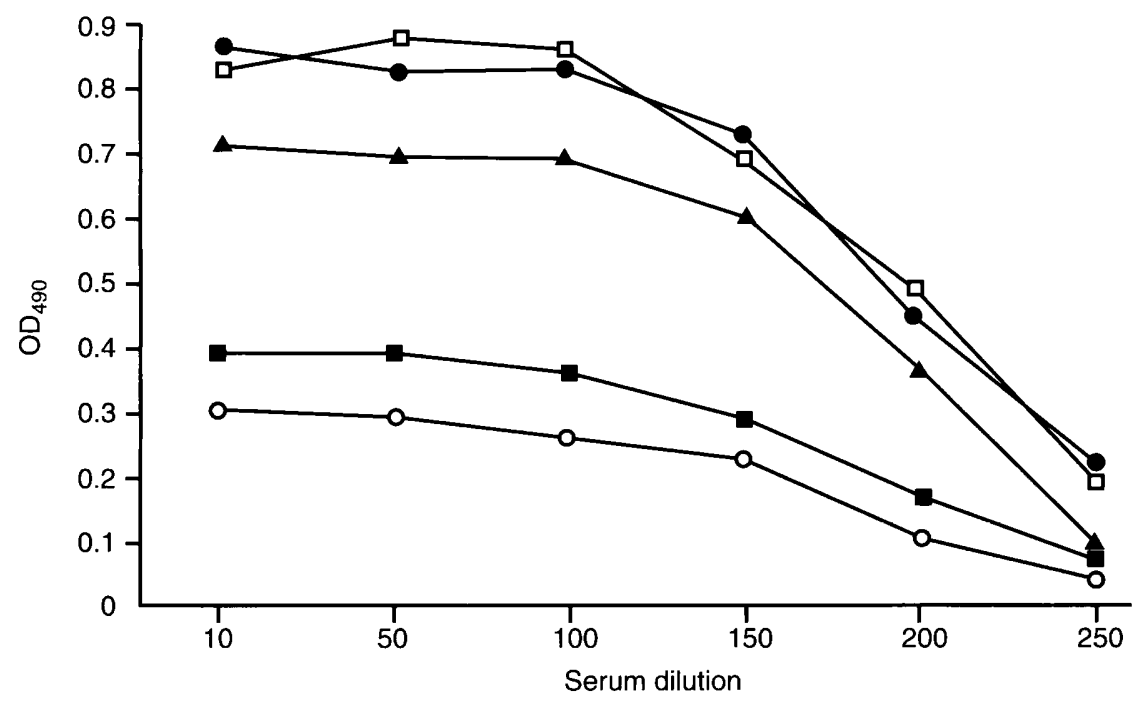

Fig. 4. Anti-ACHO antibody in human serum with ACHO-PLL complex as antigen. ELISA plates coated with ACHOPLL antigen at concentrations of $1.5 \mu \mathrm{g} / \mathrm{ml}(-\mathbf{-}-), 1 \mu \mathrm{g} / \mathrm{ml}(-\boldsymbol{\Lambda}-), 0.5 \mu \mathrm{g} / \mathrm{ml}(-\mathbf{-}-), 0.25 \mu \mathrm{g} / \mathrm{ml}(-\square-)$ and $0.15 \mu \mathrm{g} /$ $\mathrm{ml}(-\mathrm{O}-)$.

Table 1. Mean antibody titre in $\mathrm{AGN}$ and RF patients and controls assessed by ELISA with ACHO-PLL complex and enzyme-treated whole cells as antigen

\begin{tabular}{lcc}
\hline & \multicolumn{2}{c}{ Mean antibody titre (SD) with } \\
\cline { 2 - 3 } Subjects & ACHO-PLL antigen & Whole cell antigen \\
\hline AGN & $0.71(0.19)$ & $0.85(0.25)$ \\
RF & $0.63(0.12)$ & $0.77(0.27)$ \\
Controls & $0.26(0.17)$ & $0.30(0.18)$ \\
\hline
\end{tabular}

high level of antibodies to ACHO has been demonstrated in patients with rheumatic heart disease and has been utilised as a marker for persistence of rheumatic mitral valve disease [18-20].

This report describes ELISA to measure the antiACHO antibody with enzyme-treated whole cells as antigen and compares it with ELISA with purified ACHO-PLL complex. The anti-ACHO antibody titre was significantly higher in patients than in the conrol group. Comparison of ELISA results with enzymetreated whole cells as antigen with those of purified $\mathrm{ACHO}$ antigen showed significant correlation $(r=0.73)$.

T-P enzyme treatment of GAS strain $\mathrm{J}-17$, produced complete digestion of protein antigens on the cell surface and exposure of ACHO on the surface. The mechanism of action between enzyme-treated whole cells and methylglyoxal is not clearly understood. It may cross-link amino groups exposed at the bacterial surface [21] or produce an electrostatic action with polystyrene. ACHO adsorbs poorly on to plastic surfaces because of a net negative charge conferred 
by acidic groups. This was solved by conjugating ACHO to poly-L-Lysine which adsorbs strongly on to plastic surfaces.

In humans, antibodies to carbohydrate and dextran predominantly belong to the IgG2 subclass [22]. However, mice immunised with purified ACHO produce antibody of IgG3 subclass [23, 24]. Riesen et al. [22] also reported IgG3 subclass of antibody in the sera of persons with GAS infection. Todome and colleagues [11] reported IgG2 subclass antibody in the sera of normal persons and patients with RF and AGN. The present results also show that serum from normal subjects showed IgG2 subclass only. However, $3.5 \%$ of RF patients' sera and $2.5 \%$ of AGN patients' sera showed antibodies of subclass IgG3.

The ELISA technique with whole bacterial cells as antigen offers a promising alternative to other methods for the routine diagnosis of streptococcal infections and their complications because it is sensitive and easy to perform. Furthermore it avoids biohazards and the use of expensive equipment.

I am grateful to Lily and Smita Gupta, WHO Reference Laboratory for Streptococcal Disease, Department of Microbiology, Lady Hardinge Medical School, New Delhi-110001, INDIA, for constant suggestions and support.

\section{References}

1. Wannamaker LW, Ayoub EM. Antibody titers in acute rheumatic fever. Circulation 1960; 21: 598-614.

2. Harris TN, Harris S, Ogburn CA. Gel-precipitation of streptococcal culture supernatants with sera of patients with rheumatic fever and streptococcal infection. Proc Soc Exp Biol 1955; 90: $39-45$.

3. Hanson LA. Immunological analysis of streptococcal antigens and human sera by means of diffusion-in-gel methods. Int Arch Allergy 1959; 14: 279-291.

4. Hanson LA, Holm SE. Precipitating antibodies in human sera from different age groups and in colostrum as determined by streptococcal antigens with diffusion-in-gel methods. Acta Paediat (Upps) 1961; 50: 7-16.

5. Braun DG, Holm SE. Streptococcal anti-group A precipitins in sera from patients with rheumatic arthritis and glomerulonephritis. Int Arch Allergy Appl Immunol 1970; 37: 216-224.

6. Van De Rijn I, Kessler RE. Growth characteristics of group A streptococci in a new chemically defined medium. Infect Immun 1980; 27: 444-448.

7. Halpern B, Goldstein I. Utilisation du polyoside streptococcique marqué au $14 \mathrm{C}$ pour la détermination de faibles quantités d'anticorps spécifiques dans des sérums expérimentaux et humains. Rev Immunol 1964; 28: 193-204.

8. Smith $R$, Lehner $T$. A radioimmunoassay for serum and gingival crevicular fluid antibodies to a purified protein of Streptococcus mutans. Clin Exp Immunol 1981; 43: 417-424.

9. Czerkinsky C, Rees AS, Bergmeier LA, Challacombe SJ. The detection and specificity of class specific antibodies to whole bacterial cells using a solid phase radioimmunoassay. Clin Exp Immunol 1983; 53: 192-200.

10. Barrett DJ, Triggiani M, Ayoub EM. Assay of antibody to group A streptococcal carbohydrate by enzyme-linked immunosorbent assay. J Clin Microbiol 1983; 18: 622-627.

11. Todome $\mathrm{Y}$, Ohkuni $\mathrm{H}$, Yokomuro $\mathrm{K}$ et al. Enzyme-linked immunosorbent assay of antibody to group A streptococcusspecific C carbohydrate with trypsin-pronase-treated whole cell as antigen. $J$ Clin Microbiol 1988; 26: 464470.

12. Salton MRJ, Horne RW. Studies of the bacterial cell wall. II. Methods of preparation and some properties of cell walls. Biochim Biophys Acta 1951; 7: 177-197.

13. Fuller AT. The formamide method for the extraction of polysaccharides from haemolytic streptococci. BrJ Exp Pathol 1938; 19: 130-139.

14. Dische Z, Shettles LB. A specific color reaction of methylpentoses and a spectophotometric micromethod for their determination. J Biol Chem 1948; 175: 595-603.

15. Rondle CJM, Morgan WTJ. The determination of glucosamine and galactosamine. Biochem $J$ 1955; 61: 586-589.

16. Gray BM. ELISA methodology for polysaccharide antigens: protein coupling of polysaccharides for adsorption to plastic tubes. J Immunol Methods 1979; 28: 187-192.

17. McCarty M, Lancefield RC. Variation in the group-specific carbohydrate of group A streptococci: 1. Immunochemical studies on the carbohydrate of variant strains. J Exp Med 1955; 102: 11-28.

18. Ayoub EM, Shulman ST. Pattern of antibody response to the streptococcal group A carbohydrate in rheumatic patients with or without carditis. In: Read SE, Zabriskie JB (eds) Streptococcal diseases and the immune response. New York, Academic Press, Inc. 1980: 648-659.

19. Dudding BA, Ayoub EM. Persistence of streptococcal group A antibody in patients with rheumatic valvular disease. $J$ Exp Med 1968; 128: 1081-1098.

20. Shulman ST, Ayoub EM, Victorica BE, Gessner IH, Tamer DF, Hernandez FA. Differences in antibody response to streptococcal antigens in children with rheumatic and non-rheumatic mitral valve disease. Circulation 1974; 50: 1244-1251.

21. Peters K, Richards FM. Chemical cross-linking: reagents and problems in studies of membrane structure. Annu Rev Biochem 1977; 46: 523-551.

22. Riesen WF, Skvaril F, Braun DG. Natural infection of man with group A streptococci. Levels; restriction in class, subclass, and type; and clonal apperance of polysaccharide-groupspecific antibodies. Scand J Immunol 1976; 5: 383-390.

23. Perlmutter RM, Hansburg D, Briles DE, Nicolotti RA, Davie JM. Subclass restriction of murine anti-carbohydrate antibodies. J Immunol 1978; 121: 566-572.

24. Slack J, Der-balian GP, Nahm M, Davie JM. Subclass restriction of murine antibodies. II. The IgG plaque-forming cell response to thymus-independent type 1 and type 2 antigens in normal mice and mice expressing an $\mathrm{X}$-linked immunodeficiency. $J$ Exp Med 1980; 151: 853-862. 